\title{
Malaysian Secondary Students' Resilience and Entrepreneurial Readiness
}

\author{
Norasmah Othman, Radin Siti Aishah Radin A. Rahman* \\ Faculty of Education, Universiti Kebangsaan Malaysia, 43600 Bangi, Malaysia
}

Received August 1, 2020; Revised October 23, 2020; Accepted October 30, 2020

\section{Cite This Paper in the following Citation Styles}

(a): [1] Norasmah Othman, Radin Siti Aishah Radin A. Rahman, "Malaysian Secondary Students' Resilience and Entrepreneurial Readiness," Universal Journal of Educational Research, Vol. 8, No. 11A, pp. 49 - 62, 2020. DOI: 10.13189/ujer.2020.082107.

(b): Norasmah Othman, Radin Siti Aishah Radin A. Rahman (2020). Malaysian Secondary Students' Resilience and Entrepreneurial Readiness. Universal Journal of Educational Research, 8(11A), 49 - $62 . \quad$ DOI: 10.13189/ujer.2020.082107.

Copyright $\odot 2020$ by authors, all rights reserved. Authors agree that this article remains permanently open access under the terms of the Creative Commons Attribution License 4.0 International License

\begin{abstract}
This study aims to identify the level of entrepreneurship readiness and resilience of secondary school students in Selangor, Malaysia. This is measured through three elements - the student's readiness of attitude, readiness in learning, and spiritual readiness-with resilience measured using six elements: social skills, problem solving, autonomy, optimism, humor and spirituality. This study also identifies the correlation between students' entrepreneurship readiness and entrepreneurship resilience with a quantitative, surveybased approach involving 442 secondary school students. The data obtained were analyzed by descriptive and inference forms; the study's findings reveal moderate levels of entrepreneurship readiness and resilience among the surveyed secondary school students. Meanwhile, Pearson's correlation analysis demonstrates that a positive relationship exists $(\mathrm{r}=0.747)$ between entrepreneurship readiness and resilience among secondary school students. This study provides assistance to the parties involved with secondary school education, or specifically, in designing and planning entrepreneurship education, entrepreneurship training to improve entrepreneurial learning practice, students' interest and enthusiasm towards entrepreneurship. Consequently, this will enhance students' self-resilience, which indirectly creates competent and sophisticated societies.
\end{abstract}

Keywords Entrepreneurship, Entrepreneurial Readiness, Resilience, Secondary Students, Self-efficacy, Self-discipline, Self-esteem, Self-control, Selfdetermination, Self-employment

\section{Introduction}

Malaysia's Shared Prosperity Vision 2030 (SPV) policy was launched in October 2019 to replace the nation's vision 2020 policy. The 2030 policy plans for the nation's economic development and distribute Malaysian national wealth to all levels of society, regardless of ethnicity, income or supply chain. This new policy was developed to solve any remaining unsolved issues from the previous policy, such as: Malaysia's weak, lagging economic growth compared to other East Asian countries; low technological mastery; and low participation by Malaysia's Bumiputera people in various developed sectors. This latter point is especially important, as the Bumiputera's corporate equity portfolio is still low (16.2\%) compared to the National Economic Plan's target of 30\%. Further, Malaysia's foreign equity rose to $45.3 \%$, and over $60 \%$ of existing jobs over the last decade offered income of less than RM 2,000 per month [1]. As such, the SPV has been set as a benchmark for Malaysia to become a developed, highincome nation.

The nation's previously developed policies demonstrate Malaysia's capability to become a developed nation and drive its superior national economic growth; consequently, Malaysia desperately needs a highly knowledgeable and skilled workforce [2]. Zainuddin [3] also emphasized that all citizens — including students — must have the skills to fit 
the needs of the 21st century. The Ministry of Education (MoE) has also taken the initiative to design a suitable curriculum that meets the country's current needs so students have skills comparable to those of international students. This national curriculum was designed to create a balanced, resilient, curious, principled, informed, patriotic student with successful communication skills and problemsolving ability.

The government has established its Human Capital Development Policy (HCDP) to ensure resilient and competitive national human capital by 2030 , on par with foreign countries. The Strengthening Lifelong Learning policy; the third policy in particular as found in the HCDP relates to the development of students' resilience and entrepreneurship readiness and aims to enhance their skills. The policy focuses on: i) improving job skills and ii) building entrepreneurial excellence and expanding communities for high-income sectors. Part (ii) directly connects with entrepreneurship, as its strategies are implemented to enhance the effectiveness of entrepreneurship training programs and empower communities that focus on the development of entrepreneurship through training. Additionally, the fourth policy aims to improve the quality of education for a better student outcomes and institutional excellence in producing students who are resilient and competitive. Therefore, the HCDP is crucial in generating and sustaining the country's economic growth, and the availability of a highly skilled workforce is essential in transitioning all economic sectors toward knowledge-, technology-and innovation-intensive activities $[4,5]$.

In the pursuit of producing high-quality, resilient and competitive human capital to achieve the nation's aspirations, literature has also seriously focused on entrepreneurship through empowering entrepreneurship training $[5,6]$. This is because entrepreneurship is an important variable in Malaysia's economic development and growth, and is key in helping its local communities $[7,8]$. Thus, education is key in developing highly skilled, charismatic and successful human capital with an entrepreneurial mind-set, and ultimately, to achieve the nation's SPV aspirations. In fact, quality education and the mastery of skills are critical to nations' formation [9], and their true strength lies in the level of knowledge and skills possessed by its people [10].

Will these policies open students' minds and make them more resilient, competitive and ready for entrepreneurship? This question arises given the low percentage of students who choose entrepreneurship as a career, or less than two percent of all students each year, as various questionnaires have revealed the students' perceptions of entrepreneurial careers [11]. Therefore, this study is highly relevant given that resilience and entrepreneurial readiness are symbiotic, and especially in the wake of Malaysia's Industrial Revolution 4.0.

\section{Background}

The entrepreneurial field has spurred the country towards the Industrial Revolution 4.0, which parallels current technological advancements, with the potential to accelerate the country's economic growth and provide favourable career prospects for society [12]. Globalised trade, rapid technological changes, the emergence of new technologies and a global technological revolution all present the need for resilient, competitive youth.

One challenge for Malaysia in facing these changes involves producing productive, creative and innovative students who are willing to directly face the challenges ahead. This revolution demands that students be more prudent in preparing themselves to meet current demands and overcome increasingly difficult challenges [13]. This is because entrepreneurship in this era of globalisation is more challenging as technology becomes more sophisticated, competition is increasingly fierce, and workers' demands are more complex [14].

Statistics of the Malaysian labour force [15] reveal a steady unemployment rate in 2018 and 2019 of 3.3\%. However, the nation's youth are working jobs that do not reflect their educational fields, with salaries less than RM 3,000 ; this amount is not sufficient to support their daily needs. The situation appears worse when considering the increased growth of the Malaysian population over the years. According to the Department of Statistics Malaysia [16], the Malaysian population in 2019 was estimated at approximately 32.6 million people, with a population growth rate of $1.1 \%$ compared to 2018 . This growth has made it difficult for the nation's youth to find employment.

The government-and especially the MoE-has become aware of this situation, and has launched various entrepreneurship initiatives to enhance business skills and readiness among young people. This effort also involves improving the quality of education by incorporating entrepreneurial elements into both formal and informal educational curricula $[11,17,18]$.

Other than the MoE, external agencies are also working collectively to instil an entrepreneurial element among students through various entrepreneurship programs. These include the Bumiputera Youth Entrepreneurs' Program, which is a special development program in collaboration with SME Corporation Malaysia and the Ministry of International Trade and Industry. This program in particular aims to mentally and physically prepare youths who want to start businesses by exposing them to the landscape and challenges of the real business world [19]. Further, Majlis Amanah Rakyat [20] also offers special aid to new entrepreneurs through its Technical Entrepreneur Program, an initiative designed to assist entrepreneurs who want to venture into the technical field by offering training towards self-reliance in operating their own businesses. 


\section{Literature Review}

\subsection{Entrepreneurship and Entrepreneurial Readiness}

The National Entrepreneurship Policy (NEP) was introduced to provide a holistic framework or ecosystem for entrepreneurship development in Malaysia, which is rapidly growing [6]. This policy and its overall core strategy are a cornerstone of the country's resilience and competitiveness under global economic competition and the exploding technological advancements that are causally linked to the Industrial Revolution 4.0. As Malaysia must be more responsive and proactive in overcoming these challenges, the NEP was developed to achieve the following five different objectives:

1. Creating a holistic entrepreneurial ecosystem conducive to supporting Malaysia's inclusive, balanced and sustainable socio-economic development agenda.

2. Creating a society of entrepreneurial-minded and entrepreneurial-cultured people.

3. Increasing the number of high-quality, viable, resilient, global and competitive-minded entrepreneurs.

4. Enhancing the capabilities of micro, small and medium-sized enterprises and cooperatives.

5. Making entrepreneurship a widespread career option.

Producing an entrepreneurial society is also fundamental in making Malaysia a leading entrepreneurial nation by 2030. Adopting an entrepreneurial culture by implementing the NEP's five core strategies will facilitate a transformational process in the nation's inclusive economy and entrepreneurial community. Moreover, the NEP has been designed to establish a comprehensive strategic direction to develop Malaysia's entrepreneurial ecosystem. In developing Malaysia into a thriving, competitive entrepreneurial nation, it must also possess some of the following characteristics: high talent, innovation-driven, with a collaborative economy, entrepreneurial community, successful governance, market leadership and sustainable development. Two topics are to be considered and cultivated for this to be a success. First, the government should focus on promoting entrepreneurship in the entrepreneurial environment. Specifically, they should offer training, infrastructure and facilities to support entrepreneurial activities as well funding and financing and research and development to enhance entrepreneurial skills. Programs and initiatives should also be enhanced to promote these efforts' success.

Second, an entrepreneurial survey should be conducted regarding Malaysians' perceptions of entrepreneurship. An entrepreneurial culture is fostered in schools to shape students' attitudes as potential job-creators and not jobseekers [17,21]. The government established its Young Entrepreneur Program-currently the Business Growth Program - to produce more young entrepreneurs among secondary school students. The program is inspired by the
United States' Junior Achievement Program [22]. Further, the government fosters entrepreneurial culture among secondary school students through the Business Growth Program so they can engage in all fields and modern economic activities and work with non-Bumiputera citizens to develop the country [23]. Students with knowledge of training, mentorship, product marketing and capital financing can independently start their own businesses after finishing school. This knowledge can also influence their entrepreneurial success [24].

An emphasis on the Business Growth Program among secondary school students is a first step towards providing entrepreneurship guidance and knowledge. This is because students can no longer solely rely on the government to provide job opportunities and work is currently geared towards self-employment; thus, students must seize such entrepreneurial opportunities [25]. Students with an interest in business can pursue support and assistance from such existing agencies such as the Majlis Amanah Rakyat. Students can also obtain financial aid, expert guidance, training and facilities from these participating agencies after graduation. A report from the Department of Statistics Malaysia [26] reveals that few Malaysians work as entrepreneurs, with a relatively small percentage of the total population in this profession over a 25 -year period (no more than $26 \%$ ). The number of entrepreneurs has trended downward, from $25.1 \%$ in 1982 to $20.9 \%$ in 2008 . The low percentages of people working as entrepreneurs indirectly indicate that the Malaysian people are less likely and willing to venture into entrepreneurship, and more likely to pursue government or private sector employment.

Why has this situation occurred? Have youths - and especially secondary school students who have participated in an entrepreneurial co-curriculum - not been adequately prepared to venture forth as the future of entrepreneurship? The Department of Statistics Malaysia [26] demonstrates that a high percentage of those applying for entrepreneurship come from the nation's schools and universities. For example, the wholesale and retail, motor vehicle, motorcycle and personal and household repair sectors still offer employment opportunities to the younger generation, and especially graduates with a Malaysian Certificate of Education. These sectors offered employment opportunities for 26,315 (2006), 30,647 (2007), 43,948 (2008), 88,822 (2009) and 22,730 (2010) graduates [26]. Even students who have participated in entrepreneurship programs, such as the Business Growth Program, have also reported a dependency on jobs in the public or private sectors. Hence, few entrepreneurs exist among students between 15 and 34 years of age.

A similar situation can also be found overseas. For example, [27] have demonstrated that Catholic private school students have fewer and weaker entrepreneurial aspirations. Students also tend to become entrepreneurs because their schools organise entrepreneurial activities that enhance their entrepreneurial readiness and increase 
their interest in entrepreneurship. The Danish Foundation for Entrepreneurship [28] also showed that few students in Denmark (32\%) receive entrepreneurship training, although almost all students (95\%) exhibited a positive attitude towards entrepreneurship.

Globally, a 2012 statistics report from the Global Entrepreneurship Monitor found that Malaysia is still among the lowest-scoring countries in choosing entrepreneurship as a career choice, with only $51.5 \%$. The countries with the highest or moderate scores were Colombia $(89.4 \%)$, Brazil $(86.3 \%)$, China $(73.1 \%)$ and Thailand (77.0\%) [29].

\subsection{Resilience}

Resilience refers to the ability to cope with challenges in one's journey [30]. Further, Rutter [31] stated that resilience is a general ability that involves high flexibility and adaptability when handling internal or external pressures. He also observed that resilience is a universal ability to resist influences that can prevent oneself from accepting failure. Ruiz et al. [32] stated that individuals' readiness for entrepreneurship is defined as the confluence of a set of personal traits or features that distinguishes individuals with readiness for entrepreneurship. They are especially competent in observing and analysing their environments to channel their high creative and productive potential and deploy their capability to dare and need for self-achievement.

Generally, resilience is the ability to bounce back from adverse life events [33]. It is an important trait in students' well-being and success for both long-and short-term outcomes, as adversity helps children become resilient. According to Study International [34], the support children receive while experiencing adversity - and the extent to which that support meets their needs and circumstanceshelps develop resilience. Building resilience involves an ability to adapt well to adversity, trauma, tragedy, threats or even significant sources of stress. These abilities can help children manage stress and feelings of anxiety and uncertainty; however, resilience does not mean that children will not experience trouble or distress. Emotional pain and sadness are common when suffering major traumas or personal losses, or even learning of someone else's loss or trauma. Resilience can be developed in children, and involves behaviours, thoughts and actions that can be learned over time.

The aspects of resilience adapted from Masten and Reed's [35] model emphasize five key elements that reflect students' levels of resilience: self-esteem, self-discipline, self-efficacy, self-control and self-determination. The model also introduces five 'self-element' components: peer-to-peer, resilience-building, and event navigation elements. This study model denotes job success as depending on both underlying and proximal factors, including one's personality (self) and human capital. Personality is comprised of the individual's cognitive characteristics and capabilities, while human capital consists of expertise, experience, education and training, knowledge and individual skills. Integrating these basic factors can impact such proximal factors as cognition, action processes, motivations and leadership. Masten and Reed's [35] resilience model has five different dimensions derived based on the components of self-efficacy, cognition and social competence. Resilience in the efficacy element consists of various personality traits, such as optimism, persistence and great mental, physical and spiritual fitness. These personality traits dynamically influence job formation and success [36].

Masten et al. [37] also stated that resilience is 'the ability process to succeed in adapting towards changes regardless of challenging or threatening circumstances. Resilience is a word that is epistemologically derived from salire, the Latin word for 'springing up', or appearing upwards. The original word also refers to resilire, which means 'to spring back', and refers to an object's elasticity. Therefore, resilience can be regarded as the ability to rebound and endure adversity; individuals with great resilience and abilities can be described as 'tough', 'strong' or 'invincible', as well as 'tenacious' [38].

Irmohizam and Muhamad [39] discovered that students are incredibly resilient, with the following highly scoring resilience constructs: self-confidence (mean 3.78), selfefficacy (mean 3.78), self-control (mean 3.92) and determination (mean 3.81). However, the self-discipline construct scored at a moderate level (mean 3.50). The study also indicates that male students were more resilient than females $(t=3.211$ test, $p<0.001)$.

\section{Current Issues and Challenges}

The speed of the world in chasing the Industrial Revolution 4.0 calls for the rapid seizure of opportunities that can be explored to boost Malaysia's income and economic development. However, a 2018 report by the Global Entrepreneurship Research Association (GERA) [40] indicates that Malaysia is one of the few countries that still lags in its entrepreneurial readiness. This statement was obtained when the data on entrepreneurial intentions among Malaysians exhibited a low percentage of $17.6 \%$ compared to other Association of Southeast Asian Nations members, such as Indonesia (28.1\%), Vietnam (25\%) and Thailand (37.4\%) [40]. Therefore, few Malaysians are ready to enter into the field of entrepreneurship as a career, despite the government's various efforts.

Issues with entrepreneurial involvement and readiness have also been addressed among college students. For example, among community colleges, the 2017 Graduate Validation Study for Community College reported an 
increase in students' start-up their own company, with 560 students in 2016 (6.5\%) to 676 students in 2017 (6.6\%). Although students in the personal business sector increased, this occurred at a low rate, or only $0.1 \%$ [41]. This relates to the attitude of the students themselves, as noted in a study by Wahid et al. [42] of Jasin Community College final semester students; the authors' work noted that students are less confident in starting their own businesses (mean 2.50), despite an interest in entrepreneurship. This lack of involvement in entrepreneurship occurs in college as well as all other educational institutions, such as polytechnics schools or universities. For example, Mohd Halid's [43] study of South Zone Polytechnics reveals that students' entrepreneurial readiness is moderate, while the element of restraint in their attitudes is significant (mean 2.56) compared to the elements of knowledge, skills, encouragement, interest, experience, leadership and encouragement. Additionally, Madar and Abdul Hamid [44] examined the critical success factors for entrepreneurial programs in community colleges to reveal a similar issue with students who have entrepreneurial potential but lack a knowledge of entrepreneurship, confidence, creativity and innovative ideas in facing global challenges. However, Othman and Hussain's [45] study of 105 students from six different community colleges found that students are interested in becoming entrepreneurs (mean 4.01), but are not ready for such a career path because they believe entrepreneurs must overcome challenges and risks before becoming successful; therefore, these students still lack resilience. These issues are likely to affect the government's efforts in producing entrepreneurshipminded graduates and converting Malaysia into an 'entrepreneurial nation'.

Despite the government's various efforts, a lack of student involvement remains. According to Mohamad's [21] study, entrepreneurial readiness among students is only moderate, which parallels reports obtained from the Department of Labour's Employment Services Division in the year 2016. Statistics reveal that high numbers of registered job-seekers among youths who passed the Malaysian Certification of Education; the numbers of such graduating job-seekers who are still waiting for employment have fluctuated, at 28.9\% (2006), 30\% (2007), $26 \%$ (2008), 35\% (2009) and 31.9\% (2010). Meanwhile, Abd Rahim [46] stated that only moderate numbers of students tended to venture into the entrepreneurship field. Issues related to student engagement and entrepreneurship development were also debated and discussed among an entrepreneurship panel at the National Conference on the 4th Industrial Revolution 2017; clearly, students in the technical field have mastered their field of study, but still exhibit a low ability or readiness to start businesses [47]. This also reportedly relates to teachers' exposing of their students to entrepreneurship knowledge and job opportunities. Literature has also reported that teachers are unprepared, with doubtful entrepreneurial competence themselves, and consequently they fail to nurture their students' entrepreneurial readiness, resilience and competitiveness [48].

The impacts of this lack of knowledge and exposure will lead to lower students' resilience, and thus, lower entrepreneurial readiness [49]. Hence, this study was conducted among school students to 1) identify secondary students' levels of entrepreneurship, 2) identify their resilience, and 3) assess the relationship between resilience and student readiness.

\section{Methodology}

This study is concerned with issues of resilience and entrepreneurial readiness among Malaysian public school students. It aims to determine their levels of resilience and entrepreneurial readiness to ultimately produce graduates ready to launch their own entrepreneurial careers. This study was performed using a quantitative approach, with a study population of 63,308 Form Four students in Selangor, Malaysia [41] given suggestions from the MoE. Specifically, Form Four students are not involved in any major exams, and this study would not significantly interfere with their learning progress. The Malaysian state of Selangor was chosen for the study setting given its many schools compared to other states. It also has students who are homogeneous with students of other states, and the sample is much easier to access.

Many studies were referenced to determine the optimum sample size, including works by Krejcie and Morgan [50] and Sekaran and Bougie [51]. Ultimately, 460 respondents were selected, or larger than the proposed 383-student sample size. A questionnaire was used as the main instrument for estimating resilience and entrepreneurial readiness among secondary students. Resilience in this study is defined as the ability to overcome adversity and strengthen oneself through experience [52]; further, resilience is necessary for students to overcome obstacles and challenges and ensure success [41]. The resilience questionnaire was adapted from Othman et al. [53], and is divided into six parts:

1. Social skills (5 items). This includes observing one's social communication skills and exhibiting empathy, compassion and the ability to obtain other people's cooperation.

2. Problem-solving (5 items). This includes observing one's problem-solving skills, having the ability to plan and exhibit flexibility and critical, creative thinking.

3. Autonomy (4 items). This includes observing one's level of self-efficacy and exhibiting self-awareness, the ability to act independently, a locus of internal control, and adaptability towards stress; the respondent can also master something or concentrate. 
4. Optimism (5 items). This includes observing one's insights towards the future, their motivation, will to change, or ability to positively accept life and remain hopeful.

5. Humor (6 items). This includes observing one's ability to minimize stresses and difficulties with humor.

6. Spirituality (4 items). This includes observing one's belief in 'good fortune' or their culture.

Entrepreneurial readiness refers to students' desire and willingness to develop their entrepreneurial potential [23]. Self-efficacy in particular can be obtained through school programs or co-curricular or other activities aimed at gaining knowledge and developing entrepreneurial attitudes. This study defines readiness as relating to students' desire and willingness towards entrepreneurship, with three dimensions [23]: attitude readiness, learning readiness and spiritual readiness. In terms of the attitude readiness dimension (14 items), researchers wanted to discover students' attitudes toward their interests and their tendency to venture into entrepreneurship. The learning readiness dimension (15 items) involves students' processes of seeking and enhancing their entrepreneurial knowledge to build confidence and self-efficacy in becoming entrepreneurs. The spiritual readiness dimension (15 items) involves the process of identifying students' religious values in entrepreneurial traits through a spiritual fitness approach, and to discern their beliefs as reflected in their religious or spiritual values. All scales in this study were five-point Likert scales, ranging from one ('strongly disagree') to five ('strongly agree'), due to the accuracy and reliability of this type of scale [51].

Data were collected from a sample of 460 secondary students at various Malaysian secondary schools in Selangor. A self-administered questionnaire including a cover letter was delivered to the respondents during the data-collection process. Questionnaires were distributed and randomly collected by researchers during their regular classes. Of the 460 questionnaires, 442 questionnaires were deemed usable for analysis, with a response rate of $96.1 \%$.

Before the field study was conducted, a pilot study was performed to measure the questionnaire's validity and reliability. Correlations between the item and total scores were used to test validity, while Cronbach's $\alpha$ was used to test the instrument's reliability. Once analyzed, the pilot test's findings revealed that every dimension has a reliability greater than 0.7 and validity of greater than 0.3 . Therefore, the instrument is a suitable fit for this study's objectives [51]. Entrepreneurial readiness and resilience are this study's dependent and independent variables, respectively, to test their impact on secondary students' levels of entrepreneurial readiness.

\section{Findings and Discussion}

The following three research questions have been developed to identify the sample students' levels of entrepreneurial readiness and resilience while examining the relationship between them:

\subsection{What is the Level of Entrepreneurial Readiness among Secondary School Students?}

The data displayed in Table 1 reveals high entrepreneurship readiness among students, or 3.80, with a standard deviation (s.d.) of 0.45 . Only spiritual elements had a high mean of 4.05 (s.d. 0.59), while other elements were moderate, such as attitude and learning readiness. Therefore, the nature of entrepreneurship is highly influenced by the students' religious values, given their spiritual fitness and the nature of their spirituality, while their interests, attitudes and readiness towards entrepreneurship are moderate. This finding reflects previous studies [54-56], which state that students generally exhibit entrepreneurial readiness in terms of their attitudes and moderate levels of readiness to learn about entrepreneurship. They generally know the importance of entrepreneurship, but are still lacking in terms of implementation experience. Tables 2,3 and 4 provide detailed information on each element's entrepreneurial readiness.

Table 1. Levels of Entrepreneurial Readiness

\begin{tabular}{ccccc}
\hline No. & $\begin{array}{c}\text { Element of } \\
\text { Entrepreneurial } \\
\text { Readiness }\end{array}$ & Mean & $\begin{array}{c}\text { Standard } \\
\text { Deviation }\end{array}$ & Level \\
\hline 1 & Attitude Readiness & 3.51 & 0.52 & $\begin{array}{c}\text { Moderate } \\
\text { High }\end{array}$ \\
\hline 2 & $\begin{array}{c}\text { Learning } \\
\text { Readiness }\end{array}$ & 3.89 & 0.49 & $\begin{array}{c}\text { Moderate } \\
\text { High }\end{array}$ \\
\hline 3 & $\begin{array}{c}\text { Spiritual } \\
\text { Readiness }\end{array}$ & 4.01 & 0.59 & High \\
\hline $\begin{array}{c}\text { Overall Entrepreneurial } \\
\text { Readiness }\end{array}$ & 3.80 & 0.45 & $\begin{array}{c}\text { Moderate } \\
\text { High }\end{array}$ \\
\hline
\end{tabular}

Table 2 reports information on entrepreneurial readiness in terms of spirituality. The data clearly demonstrates that the percentage of students who agree and strongly agree (A + SA) on each item exceeds $50 \%$ except for the first item, which is $42.5 \%$. The percentages for this table range between $42.5 \%$ (lowest) and $79.8 \%$ (highest). Therefore, the students in general are spiritually prepared for entrepreneurial activity. They are aware that entrepreneurship is a positive activity and should be conducted fairly, honestly, and ethically. This finding indirectly indicates that Malaysia's educational policies have successfully produced holistic students as required in the National Educational Policy, which aims to produce ethical, knowledgeable students with positive attributes [57]. 
Table 2. Students' Spiritual Readiness

\begin{tabular}{|c|c|c|c|c|c|c|}
\hline No. & Items & SD & $\mathbf{D}$ & MD & $\mathbf{A}$ & SA \\
\hline 30 & I believe that $90 \%$ of sustenance occurs through business. & $\begin{array}{c}20 \\
(4.5 \%)\end{array}$ & $\begin{array}{c}33 \\
(7.5 \%) \\
\end{array}$ & $\begin{array}{c}201 \\
(45.5 \%) \\
\end{array}$ & $\begin{array}{c}112 \\
(25.3 \%) \\
\end{array}$ & $\begin{array}{c}76 \\
(17.2 \%) \\
\end{array}$ \\
\hline 31 & I believe that sustenance has been determined by God. & $\begin{array}{c}11 \\
(2.5 \%) \\
\end{array}$ & $\begin{array}{c}30 \\
(6.8 \%) \\
\end{array}$ & $\begin{array}{c}72 \\
(16.3 \%) \\
\end{array}$ & $\begin{array}{c}65 \\
(14.7 \%) \\
\end{array}$ & $\begin{array}{c}264 \\
(59.7 \%) \\
\end{array}$ \\
\hline 32 & I believe every practice starts with intent. & $\begin{array}{c}3 \\
(0.7 \%)\end{array}$ & $\begin{array}{c}12 \\
(2.7 \%)\end{array}$ & $\begin{array}{c}75 \\
(17.0 \%)\end{array}$ & $\begin{array}{c}115 \\
(26.0 \%)\end{array}$ & $\begin{array}{c}237 \\
(53.6 \%) \\
\end{array}$ \\
\hline 33 & $\begin{array}{l}\text { I believe entrepreneurial involvement is an obligation to } \\
\text { provide for the community's needs. }\end{array}$ & $\begin{array}{c}5 \\
(1.1 \%) \\
\end{array}$ & $\begin{array}{c}29 \\
(6.6 \%) \\
\end{array}$ & $\begin{array}{c}145 \\
(32.8 \%) \\
\end{array}$ & $\begin{array}{c}183 \\
(41.4 \%)\end{array}$ & $\begin{array}{c}80 \\
(18.1 \%) \\
\end{array}$ \\
\hline 34 & I often conduct myself ethically. & $\begin{array}{c}4 \\
(0.9 \%) \\
\end{array}$ & $\begin{array}{c}22 \\
(5.0 \%)\end{array}$ & $\begin{array}{c}168 \\
(38.0 \%)\end{array}$ & $\begin{array}{c}183 \\
(41.4 \%) \\
\end{array}$ & $\begin{array}{c}65 \\
(14.7 \%) \\
\end{array}$ \\
\hline 35 & I am willing to do anything to achieve my goals. & $\begin{array}{c}4 \\
(0.9 \%) \\
\end{array}$ & $\begin{array}{c}12 \\
(2.7 \%) \\
\end{array}$ & $\begin{array}{c}120 \\
(27.1 \%) \\
\end{array}$ & $\begin{array}{c}186 \\
(42.1 \%) \\
\end{array}$ & $\begin{array}{c}120 \\
(27.1 \%) \\
\end{array}$ \\
\hline 36 & I must avoid illegal and inappropriate activities. & $\begin{array}{c}6 \\
(1.4 \%) \\
\end{array}$ & $\begin{array}{c}14 \\
(3.2 \%) \\
\end{array}$ & $\begin{array}{c}75 \\
(17.0 \%) \\
\end{array}$ & $\begin{array}{c}101 \\
(22.9 \%) \\
\end{array}$ & $\begin{array}{c}246 \\
(55.7 \%) \\
\end{array}$ \\
\hline 37 & I always perform ethical activities. & $\begin{array}{c}2 \\
(0.5 \%)\end{array}$ & $\begin{array}{c}16 \\
(3.6 \%)\end{array}$ & $\begin{array}{c}159 \\
(36.0 \%) \\
\end{array}$ & $\begin{array}{c}199 \\
(45.0 \%)\end{array}$ & $\begin{array}{c}66 \\
(14.9 \%) \\
\end{array}$ \\
\hline 38 & $\begin{array}{c}\text { I will work hard to avoid practices that are considered bad in } \\
\text { religion. }\end{array}$ & $\begin{array}{c}2 \\
(0.5 \%) \\
\end{array}$ & $\begin{array}{c}19 \\
(4.3 \%) \\
\end{array}$ & $\begin{array}{c}86 \\
(19.5 \%)\end{array}$ & $\begin{array}{c}125 \\
(28.3 \%) \\
\end{array}$ & $\begin{array}{c}210 \\
(47.5 \%) \\
\end{array}$ \\
\hline 39 & I believe that God will reciprocate for our bad behaviours. & $\begin{array}{c}12 \\
(2.7 \%) \\
\end{array}$ & $\begin{array}{c}23 \\
(5.2 \%) \\
\end{array}$ & $\begin{array}{c}85 \\
(19.2 \%) \\
\end{array}$ & $\begin{array}{c}116 \\
(26.2 \%)\end{array}$ & $\begin{array}{c}206 \\
(46.6 \%) \\
\end{array}$ \\
\hline 40 & $\begin{array}{l}\text { I believe that if sustenance is blessed, God will reward us } \\
\text { with something good. }\end{array}$ & $\begin{array}{c}9 \\
(2.0 \%) \\
\end{array}$ & $\begin{array}{c}13 \\
(2.9 \%) \\
\end{array}$ & $\begin{array}{c}74 \\
(16.7 \%) \\
\end{array}$ & $\begin{array}{c}91 \\
(20.6 \%) \\
\end{array}$ & $\begin{array}{c}255 \\
(57.7 \%) \\
\end{array}$ \\
\hline 41 & I believe that every source of sustenance must be halal. & $\begin{array}{c}4 \\
(0.9 \%) \\
\end{array}$ & $\begin{array}{c}13 \\
(2.9 \%) \\
\end{array}$ & $\begin{array}{c}85 \\
(19.2 \%) \\
\end{array}$ & $\begin{array}{c}98 \\
(22.2 \%) \\
\end{array}$ & $\begin{array}{c}242 \\
(54.8 \%) \\
\end{array}$ \\
\hline 42 & I feel grateful for all the ease in my life. & - & $\begin{array}{c}11 \\
(2.5 \%) \\
\end{array}$ & $\begin{array}{c}78 \\
(17.6 \%) \\
\end{array}$ & $\begin{array}{c}139 \\
(31.4 \%) \\
\end{array}$ & $\begin{array}{c}214 \\
(48.4 \%) \\
\end{array}$ \\
\hline 43 & I must obey religious demands to show gratitude. & $\begin{array}{c}2 \\
(0.5 \%) \\
\end{array}$ & $\begin{array}{c}12 \\
(2.7 \%) \\
\end{array}$ & $\begin{array}{c}80 \\
(18.1 \%) \\
\end{array}$ & $\begin{array}{c}112 \\
(25.3 \%)\end{array}$ & $\begin{array}{c}236 \\
(53.4 \%)\end{array}$ \\
\hline 44 & I am always on time. & $\begin{array}{c}11 \\
(2.5 \%) \\
\end{array}$ & $\begin{array}{c}27 \\
(6.1 \%) \\
\end{array}$ & $\begin{array}{c}165 \\
(37.3 \%) \\
\end{array}$ & $\begin{array}{c}161 \\
(36.4 \%) \\
\end{array}$ & $\begin{array}{c}78 \\
(17.6 \%) \\
\end{array}$ \\
\hline \multicolumn{7}{|c|}{ Mean $=4.01$, S.D. $=0.59 ;$ Level $=$ High } \\
\hline
\end{tabular}

The second element of entrepreneurship readiness is learning preparedness. More than $50 \%$ of respondents answered Agree and Strongly Agree to their questions, ranging from $53.9 \%$ to $86 \%$. Items 24,17 and 27 provided low data. All of the statements in this item illustrate that students still have retained little knowledge of how to become entrepreneurs, despite the fact that they have been exposed to such knowledge from as early as age 12 . The situation worsens when the respondents conveyed that they did not enjoy visiting exhibitions (item 17), as such exhibitions can convey information about entrepreneurship and entrepreneurial activities. This relates another problem, as students tend to dislike interacting with actual entrepreneurs (item 28). In conclusion, these points must change from a learning perspective to produce entrepreneurially ready students.
This finding reflects previous research results, in that students are less interested in discovering entrepreneurial information, which is why entrepreneurial involvement is lacking among youth; they prefer traditional careers rather than entrepreneurship [21,55,56].

Entrepreneurial readiness also involves students' attitudes; Table 4 provides detailed information to indicate that students are less likely to agree with the item statements. This means that they still do not have positive attitudes towards developing a business, although they are generally aware that it is beneficial. This reflects findings, both locally and from overseas, of low entrepreneurial attitudes among students $[27,28,40,42]$. This attitude has indirectly contributed to a high unemployment rate among youths who were waiting for job opportunities and were less dedicated to creating jobs themselves. 
Table 3. Entrepreneurial Readiness_-Learning

\begin{tabular}{|c|c|c|c|c|c|c|}
\hline No. & Items & SD & D & MD & A & SA \\
\hline 15 & I enjoy reading books to improve my knowledge. & $\begin{array}{c}9 \\
(2.0 \%)\end{array}$ & $\begin{array}{c}17 \\
(3.8 \%)\end{array}$ & $\begin{array}{c}115 \\
(26.1 \%)\end{array}$ & $\begin{array}{c}193 \\
(43.7 \%)\end{array}$ & $\begin{array}{c}108 \\
(24.4 \%)\end{array}$ \\
\hline 16 & $\begin{array}{l}\text { I like to observe human behaviour to understand their } \\
\text { actions. }\end{array}$ & $\begin{array}{c}2 \\
(0.5 \%)\end{array}$ & $\begin{array}{c}17 \\
(3.8 \%)\end{array}$ & $\begin{array}{c}86 \\
(19.5 \%)\end{array}$ & $\begin{array}{c}212 \\
(48.0 \%)\end{array}$ & $\begin{array}{c}125 \\
(28.3 \%)\end{array}$ \\
\hline 17 & I like to visit exhibitions to discover new information. & $\begin{array}{c}5 \\
(1.1 \%)\end{array}$ & $\begin{array}{c}31 \\
(7.0 \%)\end{array}$ & $\begin{array}{c}150 \\
(33.9 \%)\end{array}$ & $\begin{array}{c}181 \\
(41.0 \%)\end{array}$ & $\begin{array}{c}75 \\
(17.0 \%)\end{array}$ \\
\hline 18 & I admire people who always learn something new. & $\begin{array}{c}1 \\
(0.2 \%)\end{array}$ & $\begin{array}{c}17 \\
(3.8 \%)\end{array}$ & $\begin{array}{c}79 \\
(17.9 \%)\end{array}$ & $\begin{array}{c}207 \\
46.8 \%)\end{array}$ & $\begin{array}{c}138 \\
(31.2 \%)\end{array}$ \\
\hline 19 & I am happy when I can attend any exhibition. & $\begin{array}{c}4 \\
(0.9 \%)\end{array}$ & $\begin{array}{c}19 \\
(4.3 \%)\end{array}$ & $\begin{array}{c}101 \\
(22.9 \%)\end{array}$ & $\begin{array}{c}200 \\
(45.2 \%)\end{array}$ & $\begin{array}{c}118 \\
(26.7 \%)\end{array}$ \\
\hline 20 & I am happy with how I solve problems. & $\begin{array}{c}1 \\
(0.2 \%)\end{array}$ & $\begin{array}{c}19 \\
(4.3 \%)\end{array}$ & $\begin{array}{c}169 \\
(38.2 \%)\end{array}$ & $\begin{array}{c}169 \\
(38.2 \%)\end{array}$ & $\begin{array}{c}84 \\
(19.0 \%)\end{array}$ \\
\hline 21 & $\begin{array}{l}\text { I believe that problems are challenges that do not } \\
\text { hinder my efforts. }\end{array}$ & - & $\begin{array}{c}15 \\
(3.4 \%)\end{array}$ & $\begin{array}{c}80 \\
(18.1 \%)\end{array}$ & $\begin{array}{c}217 \\
(49.1 \%)\end{array}$ & $\begin{array}{c}130 \\
(29.4 \%)\end{array}$ \\
\hline 22 & I often use mass media to find the information I need. & $\begin{array}{c}2 \\
(0.5 \%)\end{array}$ & $\begin{array}{c}17 \\
(3.8 \%)\end{array}$ & $\begin{array}{c}73 \\
(16.5 \%)\end{array}$ & $\begin{array}{c}184 \\
(41.6 \%)\end{array}$ & $\begin{array}{c}166 \\
(37.6 \%)\end{array}$ \\
\hline 23 & I often surf the Internet to find any information I need. & $\begin{array}{c}1 \\
(0.2 \%)\end{array}$ & $\begin{array}{c}12 \\
(2.7 \%)\end{array}$ & $\begin{array}{c}49 \\
(11.1 \%)\end{array}$ & $\begin{array}{c}185 \\
(41.9 \%)\end{array}$ & $\begin{array}{c}195 \\
(44.1 \%)\end{array}$ \\
\hline 24 & I know what I need to learn to become an entrepreneur. & $\begin{array}{c}2 \\
(0.5 \%)\end{array}$ & $\begin{array}{c}32 \\
(7.2 \%)\end{array}$ & $\begin{array}{c}170 \\
(38.5 \%)\end{array}$ & $\begin{array}{c}181 \\
(41.0 \%)\end{array}$ & $\begin{array}{c}57 \\
(12.9 \%)\end{array}$ \\
\hline 25 & I am ready to learn from successful entrepreneurs. & $\begin{array}{c}2 \\
(0.5 \%)\end{array}$ & $\begin{array}{c}29 \\
(6.6 \%)\end{array}$ & $\begin{array}{c}147 \\
(33.3 \%)\end{array}$ & $\begin{array}{c}174 \\
(39.4 \%)\end{array}$ & $\begin{array}{c}90 \\
(20.4 \%)\end{array}$ \\
\hline 26 & $\begin{array}{l}\text { I will try to find time to learn something that I feel is } \\
\text { important, although I am very busy. }\end{array}$ & $\begin{array}{c}3 \\
(0.7 \%)\end{array}$ & $\begin{array}{c}25 \\
(5.7 \%)\end{array}$ & $\begin{array}{c}138 \\
(31.2 \%)\end{array}$ & $\begin{array}{c}185 \\
(41.9 \%)\end{array}$ & $\begin{array}{c}91 \\
(20.6 \%)\end{array}$ \\
\hline 27 & I enjoy interacting with successful entrepreneurs. & $\begin{array}{c}4 \\
(0.9 \%)\end{array}$ & $\begin{array}{c}28 \\
(6.3 \%)\end{array}$ & $\begin{array}{c}150 \\
(33.9 \%)\end{array}$ & $\begin{array}{c}166 \\
(37.6 \%)\end{array}$ & $\begin{array}{c}94 \\
(21.3 \%)\end{array}$ \\
\hline 28 & I know when I need to learn something in more depth. & $\begin{array}{c}3 \\
(0.7 \%)\end{array}$ & $\begin{array}{c}15 \\
(3.4 \%)\end{array}$ & $\begin{array}{c}137 \\
(31.0 \%)\end{array}$ & $\begin{array}{c}207 \\
(46.8 \%)\end{array}$ & $\begin{array}{c}80 \\
(18.1 \%)\end{array}$ \\
\hline 29 & I am always curious about something. & $\begin{array}{c}2 \\
(0.5 \%) \\
\end{array}$ & $\begin{array}{c}9 \\
(2.0 \%)\end{array}$ & $\begin{array}{c}71 \\
(16.1 \%)\end{array}$ & $\begin{array}{c}194 \\
(43.9 \%)\end{array}$ & $\begin{array}{c}166 \\
(37.6 \%) \\
\end{array}$ \\
\hline
\end{tabular}

Table 4. Entrepreneurial Readiness-Attitude

\begin{tabular}{|c|c|c|c|c|c|c|}
\hline No. & Items & SD & $\mathbf{D}$ & MD & $\mathbf{A}$ & SA \\
\hline 1 & I find it easy to start a new business. & $\begin{array}{c}9 \\
(2.0 \%)\end{array}$ & $\begin{array}{c}77 \\
(17.4 \%) \\
\end{array}$ & $\begin{array}{c}241 \\
(54.5 \%)\end{array}$ & $\begin{array}{c}83 \\
(18.8 \%) \\
\end{array}$ & $\begin{array}{c}32 \\
(7.2 \%)\end{array}$ \\
\hline 2 & I find it easy to develop ideas in business. & $\begin{array}{c}7 \\
(1.6 \%) \\
\end{array}$ & $\begin{array}{c}53 \\
(12.0 \%) \\
\end{array}$ & $\begin{array}{c}217 \\
(49.1 \%) \\
\end{array}$ & $\begin{array}{c}134 \\
(30.3 \%) \\
\end{array}$ & $\begin{array}{c}31 \\
(7.0 \%) \\
\end{array}$ \\
\hline 3 & I am interested in becoming an entrepreneur as a career. & $\begin{array}{c}3 \\
(0.7 \%) \\
\end{array}$ & $\begin{array}{c}28 \\
(6.3 \%) \\
\end{array}$ & $\begin{array}{c}139 \\
(31.4 \%) \\
\end{array}$ & $\begin{array}{c}192 \\
(43.4 \%) \\
\end{array}$ & $\begin{array}{c}80 \\
(18.1 \%) \\
\end{array}$ \\
\hline 4 & I believe I have the ability to start a business. & $\begin{array}{c}3 \\
(0.7 \%) \\
\end{array}$ & $\begin{array}{c}34 \\
(7.7 \%) \\
\end{array}$ & $\begin{array}{c}199 \\
(45.0 \%) \\
\end{array}$ & $\begin{array}{c}169 \\
(38.2 \%) \\
\end{array}$ & $\begin{array}{c}37 \\
(8.4 \%) \\
\end{array}$ \\
\hline 5 & $\begin{array}{l}\text { I have the ability to control the process of starting a new } \\
\text { business. }\end{array}$ & $\begin{array}{c}5 \\
(1.1 \%) \\
\end{array}$ & $\begin{array}{c}60 \\
(13.6 \%) \\
\end{array}$ & $\begin{array}{c}251 \\
(56.8 \%)\end{array}$ & $\begin{array}{c}95 \\
(21.5 \%) \\
\end{array}$ & $\begin{array}{c}31 \\
(7.0 \%) \\
\end{array}$ \\
\hline 6 & I know all the details of how to start a business. & $\begin{array}{c}5 \\
(1.0 \%) \\
\end{array}$ & $\begin{array}{c}70 \\
(15.8 \%) \\
\end{array}$ & $\begin{array}{c}242 \\
(54.8 \%)\end{array}$ & $\begin{array}{c}101 \\
(22.9 \%)\end{array}$ & $\begin{array}{c}24 \\
(5.4 \%) \\
\end{array}$ \\
\hline 7 & Being an entrepreneur will give me great satisfaction. & $\begin{array}{c}3 \\
(0.7 \%) \\
\end{array}$ & $\begin{array}{c}35 \\
(7.9 \%) \\
\end{array}$ & $\begin{array}{c}138 \\
(31.2 \%) \\
\end{array}$ & $\begin{array}{c}188 \\
(42.5 \%) \\
\end{array}$ & $\begin{array}{c}78 \\
(17.6 \%) \\
\end{array}$ \\
\hline 8 & $\begin{array}{l}\text { Being an entrepreneur brings more benefits and } \\
\text { advantages than disadvantages to me. }\end{array}$ & $\begin{array}{c}2 \\
(0.5 \%) \\
\end{array}$ & $\begin{array}{c}24 \\
(5.4 \%) \\
\end{array}$ & $\begin{array}{c}145 \\
(32.8 \%) \\
\end{array}$ & $\begin{array}{c}183 \\
(41.4 \%) \\
\end{array}$ & $\begin{array}{c}88 \\
(19.9 \%) \\
\end{array}$ \\
\hline 9 & $\begin{array}{l}\text { My friends agree with my decision if I choose to be an } \\
\text { entrepreneur. }\end{array}$ & $\begin{array}{c}10 \\
(2.3 \%) \\
\end{array}$ & $\begin{array}{c}52 \\
(11.8 \%) \\
\end{array}$ & $\begin{array}{c}152 \\
(34.4 \%) \\
\end{array}$ & $\begin{array}{c}152 \\
(34.4 \%) \\
\end{array}$ & $\begin{array}{c}76 \\
(17.2 \%) \\
\end{array}$ \\
\hline 10 & $\begin{array}{l}\text { My friends would agree with and accept my decision to } \\
\text { start a business. }\end{array}$ & $\begin{array}{c}4 \\
(0.9 \%) \\
\end{array}$ & $\begin{array}{c}35 \\
(7.9 \%) \\
\end{array}$ & $\begin{array}{c}153 \\
(34.6 \%) \\
\end{array}$ & $\begin{array}{c}178 \\
(40.3 \%) \\
\end{array}$ & $\begin{array}{c}72 \\
(16.3 \%) \\
\end{array}$ \\
\hline 11 & $\begin{array}{l}\text { My immediate family would agree with my decision to } \\
\text { venture into the business world. }\end{array}$ & $\begin{array}{c}3 \\
(0.7 \%) \\
\end{array}$ & $\begin{array}{c}25 \\
(5.7 \%)\end{array}$ & $\begin{array}{c}137 \\
(31.0 \%)\end{array}$ & $\begin{array}{c}175 \\
(39.6 \%) \\
\end{array}$ & $\begin{array}{c}102 \\
(23 . \%)\end{array}$ \\
\hline 12 & $\begin{array}{l}\text { If I had the opportunity, I would love to start my own } \\
\text { business. }\end{array}$ & $\begin{array}{c}1 \\
(0.2 \%) \\
\end{array}$ & $\begin{array}{c}20 \\
(4.5 \%) \\
\end{array}$ & $\begin{array}{c}132 \\
(29.9 \%)\end{array}$ & $\begin{array}{c}180 \\
(40.7 \%)\end{array}$ & $\begin{array}{c}109 \\
(24.7 \%) \\
\end{array}$ \\
\hline 13 & $\begin{array}{l}\text { If I started a business, I would have a high chance of } \\
\text { success. }\end{array}$ & $\begin{array}{c}2 \\
(0.5 \%) \\
\end{array}$ & $\begin{array}{c}23 \\
(5.2 \%) \\
\end{array}$ & $\begin{array}{c}194 \\
(43.9 \%) \\
\end{array}$ & $\begin{array}{c}171 \\
(38.7 \%) \\
\end{array}$ & $\begin{array}{c}52 \\
11.8 \%) \\
\end{array}$ \\
\hline 14 & $\begin{array}{l}\text { Among many options, it is best for me to venture into the } \\
\text { entrepreneurship field. }\end{array}$ & $\begin{array}{c}4 \\
(0.9 \%) \\
\end{array}$ & $\begin{array}{c}49 \\
(11.1 \%) \\
\end{array}$ & $\begin{array}{c}205 \\
(46.4 \%) \\
\end{array}$ & $\begin{array}{c}129 \\
(29.2 \%) \\
\end{array}$ & $\begin{array}{c}55 \\
(12.4 \%) \\
\end{array}$ \\
\hline \multicolumn{7}{|c|}{ Mean $=3.51$, S.D. $=0.52 ;$ Level $=$ Moderately High } \\
\hline
\end{tabular}




\subsection{What is the Level of Resilience among Secondary School Students?}

Table 5. Levels of Resilience

\begin{tabular}{ccccc}
\hline No. & Resilience Element & Mean & $\begin{array}{c}\text { Standard } \\
\text { Deviation }\end{array}$ & Level \\
\hline 1 & Social Skills & 3.94 & 0.57 & $\begin{array}{c}\text { Moderately } \\
\text { High }\end{array}$ \\
\hline 2 & Problem-Solving & 3.58 & 0.58 & $\begin{array}{c}\text { Moderately } \\
\text { High }\end{array}$ \\
\hline 3 & Autonomy & 3.76 & 0.63 & $\begin{array}{c}\text { Moderately } \\
\text { High }\end{array}$ \\
\hline 4 & Optimism & 3.85 & 0.63 & $\begin{array}{c}\text { Moderately } \\
\text { High }\end{array}$ \\
\hline 5 & Humour & 3.73 & 0.72 & $\begin{array}{c}\text { Moderately } \\
\text { High }\end{array}$ \\
\hline 6 & Spirituality & 4.21 & 0.80 & High \\
\hline & Overall Resilience & 3.84 & 0.48 & $\begin{array}{c}\text { Moderately } \\
\text { High }\end{array}$ \\
\hline
\end{tabular}

Resilience is divided into the following six elements: social skills, problem-solving, autonomy, optimism, humor and spirituality. Upon analysis, the students' resilience was found to be high, with a mean of 3.84 and standard deviation of 0.48 . The data acquisition reveals the same results as with the entrepreneurial readiness data, in that the spiritual element has the highest mean. The mean level of resilience in the spirituality aspect is 4.21 , with a standard deviation of 0.80 . This is followed by social skills, while problem-solving exhibits the lowest values of these six elements, as demonstrated in the following Table 5.

The following Tables 6 through 11 provide a clearer illustration of each item. Regarding the social skills element, items 1 and 2 had the highest percentages, which indicates explains that students can work together and build good relationships with those around them, regardless of race or religion. This process will increase students' confidence and resilience even when in the public eye.

Table 7 examines secondary school students' problemsolving-based resilience in more detail. As item 8 has the lowest percentage (Agree + Strongly Agree), students are less likely to plan their daily activities; further, they will only perform activities at certain or appropriate times (item 7).

Table 6. Social Skills

\begin{tabular}{|c|c|c|c|c|c|c|}
\hline No. & Items & SD & $\mathrm{D}$ & MD & A & SA \\
\hline 1 & I can work with anyone regardless of race or religion. & $\begin{array}{c}2 \\
(0.5 \%) \\
\end{array}$ & $\begin{array}{c}14 \\
(3.2 \%) \\
\end{array}$ & $\begin{array}{c}82 \\
(18.6 \%) \\
\end{array}$ & $\begin{array}{c}204 \\
(46.2 \%) \\
\end{array}$ & $\begin{array}{c}140 \\
(31.7 \%) \\
\end{array}$ \\
\hline 2 & I cooperate with people around me. & - & $\begin{array}{c}13 \\
(2.9 \%) \\
\end{array}$ & $\begin{array}{c}78 \\
(17.6 \%) \\
\end{array}$ & $\begin{array}{c}239 \\
(54.1 \%) \\
\end{array}$ & $\begin{array}{c}112 \\
(25.3 \%) \\
\end{array}$ \\
\hline 3 & I always forgive other people's mistakes. & $\begin{array}{c}4 \\
(0.9 \%) \\
\end{array}$ & $\begin{array}{c}13 \\
(2.9 \%) \\
\end{array}$ & $\begin{array}{c}117 \\
(26.5 \%) \\
\end{array}$ & $\begin{array}{c}205 \\
(46.4 \%) \\
\end{array}$ & $\begin{array}{c}103 \\
(23.3 \%) \\
\end{array}$ \\
\hline 4 & I have good relationships with other people. & - & $\begin{array}{c}8 \\
(1.8 \%)\end{array}$ & $\begin{array}{c}115 \\
(26.0 \%)\end{array}$ & $\begin{array}{c}216 \\
(48.9 \%)\end{array}$ & $\begin{array}{c}103 \\
(23.3 \%)\end{array}$ \\
\hline 5 & I can easily gain others' cooperation. & $\begin{array}{c}4 \\
(0.9 \%)\end{array}$ & $\begin{array}{c}10 \\
(2.3 \%)\end{array}$ & $\begin{array}{c}143 \\
(32.4 \%)\end{array}$ & $\begin{array}{c}205 \\
(46.4 \%)\end{array}$ & $\begin{array}{c}80 \\
(18.1 \%)\end{array}$ \\
\hline
\end{tabular}

Mean $=3.96$, S.D. $=0.57 ;$ Level $=$ Moderately High

Table 7. Problem-Solving

\begin{tabular}{|c|c|c|c|c|c|c|}
\hline No. & Items & SD & $\mathrm{D}$ & MD & A & SA \\
\hline 6 & I react quickly when faced with a crisis. & $\begin{array}{c}3 \\
(0.7 \%)\end{array}$ & $\begin{array}{c}22 \\
(5.0 \%)\end{array}$ & $\begin{array}{c}200 \\
(45.2 \%)\end{array}$ & $\begin{array}{c}168 \\
(38.0 \%)\end{array}$ & $\begin{array}{c}49 \\
(11.1 \%)\end{array}$ \\
\hline 7 & I act at the right time. & $\begin{array}{c}1 \\
(0.2 \%)\end{array}$ & $\begin{array}{c}16 \\
(3.6 \%)\end{array}$ & $\begin{array}{c}159 \\
(36 \%)\end{array}$ & $\begin{array}{c}215 \\
(48.6 \%)\end{array}$ & $\begin{array}{c}51 \\
(11.5 \%)\end{array}$ \\
\hline 8 & I always plan my activities. & $\begin{array}{c}3 \\
(0.7 \%) \\
\end{array}$ & $\begin{array}{c}25 \\
(5.7 \%) \\
\end{array}$ & $\begin{array}{c}177 \\
(40.0 \%)\end{array}$ & $\begin{array}{c}171 \\
(38.7 \%)\end{array}$ & $\begin{array}{c}66 \\
(4.9 \%) \\
\end{array}$ \\
\hline 9 & I always have the confidence to act even if others may reject my ideas. & $\begin{array}{c}2 \\
(0.5 \%) \\
\end{array}$ & $\begin{array}{c}27 \\
(6.1 \%)\end{array}$ & $\begin{array}{c}180 \\
(40.7 \%)\end{array}$ & $\begin{array}{c}175 \\
(39.6 \%) \\
\end{array}$ & $\begin{array}{c}58 \\
(13.1 \%) \\
\end{array}$ \\
\hline 10 & $\begin{array}{l}\text { I always finish a task immediately even if there is no pressure to finish it } \\
\text { immediately. }\end{array}$ & $\begin{array}{c}4 \\
(0.9 \%) \\
\end{array}$ & $\begin{array}{c}33 \\
(7.5 \%) \\
\end{array}$ & $\begin{array}{c}199 \\
(45.0 \%)\end{array}$ & $\begin{array}{c}158 \\
(35.7 \%) \\
\end{array}$ & $\begin{array}{c}48 \\
(10.9 \%) \\
\end{array}$ \\
\hline \multicolumn{7}{|c|}{ Mean $=3.58$, S.D. $=0.58 ;$ Level $=$ Moderately High } \\
\hline
\end{tabular}


Table 8. Autonomy

\begin{tabular}{|c|c|c|c|c|c|c|}
\hline No. & Items & SD & $\mathrm{D}$ & MD & A & SA \\
\hline 11 & I am willing to face any hardship in my life. & $\begin{array}{c}3 \\
(0.7 \%) \\
\end{array}$ & $\begin{array}{c}16 \\
(3.6 \%) \\
\end{array}$ & $\begin{array}{c}131 \\
(29.6 \%) \\
\end{array}$ & $\begin{array}{c}205 \\
(46.4 \%) \\
\end{array}$ & $\begin{array}{c}87 \\
(19.7 \%) \\
\end{array}$ \\
\hline 12 & I have high resilience. & - & $\begin{array}{c}28 \\
(6.3 \%)\end{array}$ & $\begin{array}{c}174 \\
(39.4 \%)\end{array}$ & $\begin{array}{c}171 \\
(38.7 \%)\end{array}$ & $\begin{array}{c}69 \\
(15.6 \%) \\
\end{array}$ \\
\hline 13 & I am an independent person. & $\begin{array}{c}1 \\
(0.2 \%) \\
\end{array}$ & $\begin{array}{c}20 \\
(4.5 \%) \\
\end{array}$ & $\begin{array}{c}139 \\
(31.4 \%) \\
\end{array}$ & $\begin{array}{c}200 \\
(45.2 \%) \\
\end{array}$ & $\begin{array}{c}82 \\
(18.6 \%) \\
\end{array}$ \\
\hline 14 & I am not easily discouraged by failure. & $\begin{array}{c}2 \\
(0.5 \%) \\
\end{array}$ & $\begin{array}{c}23 \\
(5.2 \%) \\
\end{array}$ & $\begin{array}{c}124 \\
(28.1 \%) \\
\end{array}$ & $\begin{array}{c}195 \\
(44.1 \%) \\
\end{array}$ & $\begin{array}{c}98 \\
(22.2 \%) \\
\end{array}$ \\
\hline
\end{tabular}

Table 9. Optimism

\begin{tabular}{|c|c|c|c|c|c|c|}
\hline No. & Items & SD & $\mathrm{D}$ & MD & A & SA \\
\hline 15 & I find my life very meaningful. & $\begin{array}{c}10 \\
(2.3 \%) \\
\end{array}$ & $\begin{array}{c}15 \\
(3.4 \%) \\
\end{array}$ & $\begin{array}{c}119 \\
(26.9 \%) \\
\end{array}$ & $\begin{array}{c}189 \\
(42.8 \%) \\
\end{array}$ & $\begin{array}{c}109 \\
(24.7 \%) \\
\end{array}$ \\
\hline 16 & I can adapt to new social environments. & $\begin{array}{c}4 \\
(0.9 \%) \\
\end{array}$ & $\begin{array}{c}26 \\
(5.9 \%) \\
\end{array}$ & $\begin{array}{c}124 \\
(28.1 \%) \\
\end{array}$ & $\begin{array}{c}204 \\
(46.2 \%) \\
\end{array}$ & $\begin{array}{c}84 \\
(19.0 \%) \\
\end{array}$ \\
\hline 17 & I can motivate myself to achieve great results. & $\begin{array}{c}2 \\
(0.5 \%) \\
\end{array}$ & $\begin{array}{c}14 \\
(3.2 \%) \\
\end{array}$ & $\begin{array}{c}129 \\
(29.2 \%) \\
\end{array}$ & $\begin{array}{c}213 \\
(48.2 \%) \\
\end{array}$ & $\begin{array}{c}84 \\
(19.0 \%) \\
\end{array}$ \\
\hline 18 & I seek various alternatives to achieve my goals. & $\begin{array}{c}2 \\
(0.5 \%)\end{array}$ & $\begin{array}{c}16 \\
(3.6 \%) \\
\end{array}$ & $\begin{array}{c}133 \\
(30.1 \%) \\
\end{array}$ & $\begin{array}{c}197 \\
(44.6 \%) \\
\end{array}$ & $\begin{array}{c}94 \\
(21.3 \%) \\
\end{array}$ \\
\hline 19 & I am sure that everything will be fine. & $\begin{array}{c}1 \\
(0.2 \%) \\
\end{array}$ & $\begin{array}{c}15 \\
(3.4 \%) \\
\end{array}$ & $\begin{array}{c}101 \\
(22.9 \%) \\
\end{array}$ & $\begin{array}{c}195 \\
(44.1 \%) \\
\end{array}$ & $\begin{array}{c}130 \\
(29.4 \%) \\
\end{array}$ \\
\hline
\end{tabular}

Table 10. Humour

\begin{tabular}{|c|c|c|c|c|c|c|}
\hline No. & Items & SD & $\mathrm{D}$ & MD & A & SA \\
\hline 20 & I often make others laugh. & $\begin{array}{c}11 \\
(2.5 \%)\end{array}$ & $\begin{array}{c}24 \\
(5.4 \%)\end{array}$ & $\begin{array}{c}138 \\
(31.2 \%)\end{array}$ & $\begin{array}{c}151 \\
(34.2 \%)\end{array}$ & $\begin{array}{c}118 \\
(26.7 \%)\end{array}$ \\
\hline 21 & I can ease tension in a situation by saying something funny. & $\begin{array}{c}5 \\
(1.1 \%) \\
\end{array}$ & $\begin{array}{c}32 \\
(7.2 \%) \\
\end{array}$ & $\begin{array}{c}157 \\
(35.5 \%) \\
\end{array}$ & $\begin{array}{c}150 \\
(33.9 \%)\end{array}$ & $\begin{array}{c}98 \\
(22.2 \%) \\
\end{array}$ \\
\hline 22 & I can speak in my own style and make others laugh. & $\begin{array}{c}5 \\
(1.1 \%) \\
\end{array}$ & $\begin{array}{c}25 \\
(5.7 \%) \\
\end{array}$ & $\begin{array}{c}139 \\
(31.4 \%) \\
\end{array}$ & $\begin{array}{c}147 \\
(33.3 \%) \\
\end{array}$ & $\begin{array}{c}126 \\
(28.5 \%) \\
\end{array}$ \\
\hline 23 & I always think of something humorous to relieve stress. & $\begin{array}{c}3 \\
(0.7 \%)\end{array}$ & $\begin{array}{c}30 \\
(6.8 \%)\end{array}$ & $\begin{array}{c}132 \\
(29.9 \%)\end{array}$ & $\begin{array}{c}181 \\
(41.0 \%)\end{array}$ & $\begin{array}{c}96 \\
(21.7 \%)\end{array}$ \\
\hline 24 & Humour has helped me overcome difficult situations. & $\begin{array}{c}7 \\
(1.6 \%)\end{array}$ & $\begin{array}{c}25 \\
(5.7 \%)\end{array}$ & $\begin{array}{c}143 \\
(32.4 \%)\end{array}$ & $\begin{array}{c}172 \\
(38.9 \%)\end{array}$ & $\begin{array}{c}95 \\
(21.5 \%)\end{array}$ \\
\hline 25 & Other people often say that I always talk about something funny. & $\begin{array}{c}8 \\
(1.8 \%)\end{array}$ & $\begin{array}{c}36 \\
(8.1 \%)\end{array}$ & $\begin{array}{c}180 \\
(40.7 \%)\end{array}$ & $\begin{array}{c}126 \\
(28.5 \%)\end{array}$ & $\begin{array}{c}92 \\
(20.8 \%)\end{array}$ \\
\hline
\end{tabular}

Similar results are observed regarding resilience and autonomy in Table 8 . All items indicated that over $50 \%$ of the respondents responded with agreement and strong agreement. However, the percentage of Agree + Strongly Agree ranges from $54.3 \%$ to $66.3 \%$, which indicates that secondary school students have autonomy, but at a moderate level. Their resilience in this aspect can be enhanced with teachers' help in the classroom.

Table 9 provides further detail regarding secondary school students' resilience based on optimism. All items indicate that over $65 \%$ of the respondents chose Agree + Strongly Agree, resulting in a mean of 3.85, closer to high, and a standard deviation of 0.63 . The percentage range for Agree + Strongly Agree ranges from 65.2\% to 73.5\%. Item 19 exhibited the highest percentage (73.9\%). Collectively, these items reveal students' high confidence in themselves.

Table 10 provides further detail regarding secondary school students' resilience based on optimism. All items indicate that over $65 \%$ of the respondents chose Agree + Strongly Agree, resulting in a mean of 3.85, closer to high, and a standard deviation of 0.63 . The percentage range for Agree + Strongly Agree ranges from 65.2\% to 73.5\% . Item 19 exhibited the highest percentage $(73.9 \%)$. Collectively, these items reveal students' high confidence in themselves.

Regarding humor (Table 10), the percentages of respondents who chose Agree ranged from $49.3 \%$ to $62.7 \%$. The percentage of respondents who chose Disagree was also high, ranging from $29.9 \%$ to $40.7 \%$. These results are evident from the mean score of 3.85 and standard deviation of 0.63 , which may indicate that students still cannot perceive the problems they are experiencing as normal. These students still require more time to adapt and familiarize themselves with various types of adversity so they can adequately recover if they encounter any challenges. 
Table 11. Spirituality

\begin{tabular}{|c|c|c|c|c|c|c|}
\hline No & Items & SD & $\mathrm{D}$ & MD & A & SA \\
\hline 26 & I depend on God to control my life. & $\begin{array}{c}102 \\
(2.3 \%) \\
\end{array}$ & $\begin{array}{c}26 \\
(5.9 \%) \\
\end{array}$ & $\begin{array}{c}108 \\
(24.4 \%) \\
\end{array}$ & $\begin{array}{c}143 \\
(32.4 \%) \\
\end{array}$ & $\begin{array}{c}155 \\
(35.1 \%) \\
\end{array}$ \\
\hline 27 & I know God is always there to help. & $\begin{array}{c}5 \\
(1.1 \%) \\
\end{array}$ & $\begin{array}{c}12 \\
(2.7 \%) \\
\end{array}$ & $\begin{array}{c}67 \\
(15.2 \%) \\
\end{array}$ & $\begin{array}{c}122 \\
(27.6 \%) \\
\end{array}$ & $\begin{array}{c}236 \\
(53.4 \%) \\
\end{array}$ \\
\hline 28 & $\begin{array}{l}\text { I am sure that there is wisdom behind everything that is happening in } \\
\text { my life. }\end{array}$ & $\begin{array}{c}2 \\
(0.5 \%)\end{array}$ & $\begin{array}{c}11 \\
(2.5 \%)\end{array}$ & $\begin{array}{c}69 \\
(15.6 \%)\end{array}$ & $\begin{array}{c}121 \\
(27.4 \%)\end{array}$ & $\begin{array}{c}239 \\
(54.1 \%) \\
\end{array}$ \\
\hline 29 & After praying to God, I feel strong or excited. & $\begin{array}{c}41 \\
(0.9 \%) \\
\end{array}$ & $\begin{array}{c}12 \\
(2.7 \%) \\
\end{array}$ & $\begin{array}{c}72 \\
(16.3 \%) \\
\end{array}$ & $\begin{array}{c}120 \\
(27.1 \%) \\
\end{array}$ & $\begin{array}{c}234 \\
(52.9 \%) \\
\end{array}$ \\
\hline
\end{tabular}

As Table 11 illustrates, a high percentage of people agree with the spirituality aspect, ranging from $67.5 \%$ to $81.5 \%$. Further, students' resilience regarding the spirituality aspect was higher than with the other five aspects, a finding that reflects entrepreneurial readiness from the spirituality perspective. Although the percentages of resilience and entrepreneurial readiness are moderately high, the spirituality aspect is also high; therefore, secondary school students possess the faith and beliefs to face various obstacles in their lives. This aspect also closely connects to the effectiveness of the education that the government seeks to implement by establishing values in its educational system [57].

\subsection{Does a Significant Relationship Exist between Secondary School Students' Entrepreneurial Readiness and Resilience?}

H01: No significant relationship exists between secondary school students' entrepreneurial readiness and resilience.

Table 12 presents the findings related to the relationship between secondary school students' entrepreneurial readiness and resilience, with values of $r=0.747$ and $p<$ 0.05 . Therefore, a strong relationship exists between resilience and entrepreneurial readiness, and thus, the null hypothesis is rejected. This study parallels statements from Mohamad [21], and Ab Wahid [55], as these authors also mentioned that a correlation exists between entrepreneurial readiness and student resilience; Fatoki's [58] study of small and medium-sized entrepreneurs in Africa revealed the same results. Subsequently, the relationship between these two variables impacts both the students and entrepreneurs.

Table 12. Pearson's Correlation for Secondary School Students' Entrepreneurial Readiness and Resilience

\begin{tabular}{ccc}
\hline & & Resilience \\
\hline Entrepreneurial readiness & $\begin{array}{c}\text { Pearson's } \\
\text { correlation } \\
\text { Sig. (two-tailed) }\end{array}$ & 0.747 \\
& & 0.000 \\
& 422 \\
\hline
\end{tabular}

\section{Conclusions}

More research is needed in the entrepreneurial field in a
Malaysian context, as the nation is experiencing unprecedented demand and business growth. Therefore, programs on entrepreneurship and entrepreneurial training should be considered to improve the situation in secondary schools. Further, the secondary school curriculum should be examined and revised, with new courses on entrepreneurship introduced into the curriculum.

Entrepreneurship has been found to be an important driver of economic growth, productivity and social development [59]. Moreover, Bakotic and Kruzic [60] noted that the promotion of entrepreneurship has become a primary issue in most industrial countries' public policies. In this context, many countries' governments have increasingly fostered entrepreneurship through education and training. As one critical element to increase students' involvement in the entrepreneurship field is resilience, this study focuses on two factors: students' resilience and their entrepreneurial readiness.

Excellent academic achievements do not guarantee employment due to currently intense industry competition [61]. An increasing number of university graduates in Malaysia has led to more intense competition, and secondary school graduates are less likely to gain the jobs they desire. Therefore, venturing into the entrepreneurship field is the best solution for the nation's unemployment as people will no longer depend on a monthly salary, but can create additional job opportunities by owning their own business.

The most significant issue in terms of education and skills involves the difficulty in balancing supply and demand in the various sectors. The excessive number of graduates with only academic certificates, but no additional skills, has compelled employers to select only a few students for hire. Simultaneously, many graduates are forced into choosing a career that does not match their qualifications. Highly skilled graduates must foster their innovative abilities and creativity to explore new fields and shift their perspectives from job-seekers to job-creators. This is particularly significant given the increasingly competitive job market. Therefore, students' resilience and entrepreneurial readiness should be strengthened, and especially as this study has discovered secondary students have moderately high levels of entrepreneurial readiness and resilience. These findings also reveal a strong correlation between these two factors. Thus, Malaysia's 
Ministry of Education, policy-makers and entrepreneurship educators must re-evaluate their programs and academic to positively impact students who have not yet demonstrated any favorable results.

Meaning, the parties involved with secondary school education, or specifically, in designing and planning entrepreneurship education, entrepreneurship training need to re-evaluate or reconstruct the curriculum or syllabus in order to improve entrepreneurial learning practice, students' interest and enthusiasm towards entrepreneurship. These changes will enhance students' self-resilience and entrepreneurial readiness which indirectly creates competent and entrepreneurial societies that fit with the needs of the $21^{\text {st }}$ century or Industrial Revolution 4.0.

\section{Acknowledgements}

The author acknowledges the financial support from Faculty of Education, Universiti Kebangsaan Malaysia Grant GG-2019-036.

\section{REFERENCES}

[1] Malaysia. Shared Prosperity Vision 2030. Prime Minister Department, Putrajaya Malaysia, 2019a.

[2] Z. H. Mohamed Ashari. Structural equation modelling career selection of Malaysian skills certification system. PhD thesis, Universiti Kebangsaan Malaysia, Bandar Baru Bangi, 2016.

[3] F. Zainuddin. 21 ${ }^{\text {st }}$ century skills, 2015. Available from https://sumberdigital.wordpress.com/2015/10/31/kemahiran -abad-ke-21/ Accessed date 24.04.2020.

[4] S. Soemitro. Contribution of human capital investment to economic development, Pembangunan Modal Insamn: Isu dan Cabaran. Penerbit UKM, Bangi, 2010.

[5] Economy Planning Unit. Vision2020, 1991-2020, 2017. Available from, http://www.epu.gov.my/ms/dasarutama/wawasan-2020 Accessed date 24.04.2020.

[6] Ministry Entrepreneurship Development. National Entrepreneurial Policy, Putrajaya Malaysia, 2010.

[7] H. Kaur, A. Bains. Understanding the concept of entrepreneur competency. Journal of Business Management \& Social Sciences Research, Vol. 2, No. 11, 31-33, 2013.

[8] J. A. Moriano, M. Gorgievski, M. Laguna, U. Stephan, K. Zarafshani. A cross-cultural approach to understanding entrepreneurial intention. Journal of Career Development, Vol. 39, No. 2, 162-185, 2012. doi: 10.1177/089484531038 4481

[9] Z. Zulkifli. Effectiveness of problem-based learning methods in improving high-level thinking skills and problem solving among students. Master's thesis, Universiti Tun Hussein Onn Malaysia, Batu Pahat, 2016.

[10] N. S. Rajendran. Teaching higher-level thinking skills: teacher readiness to control the learning process, Seminar
Project KBKK: Poster Warisan-Pendidikan-Wawasan, pp.113. 1-2, 2001. Achieved from https://www.academia.edu/26065656/Pengajaran_Kemahira n_Berfikir_Aras_Tinggi_Kesediaan_Guru_Mengendalikan _Proses_Pengajaran_Pembelajaran Accessed date 24.04.2020.

[11] Ministry of Education. Assessment and Curriculum Standard Document. Educational Resources and Technology, Putrajaya, Malaysia, 2019.

[12] A. Mokhtar. A study of competencies that influence entrepreneur performance in retail business ventures in Malaysia. Doctoral Thesis, Australia, Southern Cross University, 2017.

[13] L. Collins, P. D. Hannon, A. Smith. Enacting entrepreneurial intent: the gaps between student needs and higher education capability. Education + Training, Vol. 46, No. 8/9, 454-463, 2004. doi: 10.1108/00400910410569579

[14] A. A. Yusof. Introduction to Entrepreneurs and Entrepreneurship. ScholarMind Publishing, Kuala Lumpur, 2010.

[15] Malaysia. Current population statistics for 2018/2019, $2019 \mathrm{~b}$. Available fromhttp://www.gcarian.com/statistik-pendudukmalaysia.jsp Accessed date 24.04.2020.

[16] Department of Statistics Malaysia. Latest statistics of Malaysian population 2018/2019, 2020. Available from https://www.gcarian.com/statistik-penduduk-malaysia.jsp Accessed date 25.04.2020.

[17] N. Othman, N. H. Othman, B. T. Poo, R. Ismail. The impact of globalization and entrepreneurial career choice among university students. Proseding Perkem VII, Vol. 1, 435-445, 2012.

[18] Economy Planning Unit. 11th Malaysian Planning. Putrajaya, Malaysia, 2015.

[19] SME Corporation Malaysia. Youth entrepreneurship program 2016, Available from http://tube.smecorp.gov.my/i ndex.php Accessed date 10.08.2017.

[20] Majlis Amanah Rakyat. Entrepreneurship, 2018. Available from http://www.mara.gov.my/program-usahawan-teknikalputek- Accessed date 07.09.2018.

[21] R. Mohamad. Entrepreneurial self-efficacy and entrepreneurial competency towards the entrepreneurial inclination of pre-university students. Master's thesis, Universiti Kebangsaan Malaysia, Bandar Baru Bangi, 2017.

[22] M. Saadon, Factors influencing the involvement of fourthgeneration vocational students in undertaking entrepreneurial activities in secondary technical schools. Bachelors of Technology and Education (Electrical Engineering), Final project, Universiti Teknologi Malaysia, Skudai, Johor, 2004.

[23] N. Hashim, N. Othman, N. Buang, Entrepeneurial Readiness Concept Based on SME Entrepreneur Case Study in Malaysia. Jurnal Pendidikan Malaysia, Vol. 34, No. 1, 187 203, 2009.

[24] N. Othman, M. Gaya. The level of knowledge of MARA Institute trainees for an environment conducive for prospective entrepreneurs. Jurnal Teknologi, Vol. 50, 53-67, 2009. 
[25] N. Othman, R. Hassan, W. M. N. Wan Zaki. Basic Entrepreneurship Education. Penerbit Universiti Kebangsaan Malaysia, Bangi, 2018.

[26] Department of Statistics Malaysia. Malaysian labour investigation report, 2011. Available from: https://www.academia.edu/5367835/Jabatan_Perangkaan_ Malaysia_Department_Of_Statistics_Malaysia Accessed date 24.04.2020.

[27] O. Falck, L. Woessmann. School competition and students' entrepreneurial intentions: International evidence using historical Catholic roots of private schooling. working paper, Program on Education Policy and Governance, Harvard University, Cambridge, MA, 2010.

[28] Danish Foundation for Entrepreneurship. Impact of entrepreneurship education in Denmark 2011, Fonden Four Entrepren0skab: Young Entreprise Danmark. 2011. Available from: https://eng.ffeye.dk/media/202248/impact_of_entrepreneurs hip_education_in_denmark_2011.pdf. Accessed date: 24.04.2020.

[29] D. J. Kelley, S. Singer, M. Herrington. Global Entrepreneurship Monitor 2011 Global Report. Global Entrepreneurship Research Association, London Business School, London, 2012.

[30] S. Covey. The Seven Habits of Highly Effective People, Free Press, New York, NY, 1989.

[31] M. Rutter. Resilience concepts and findings: implications for family therapy. Journal of Family Therapy, Vol. 21, 119-144, 1999.

[32] J. Ruiz, D. R. Soriano, A. Coduras. Challenges in measuring readiness for entrepreneurship. Management Decision, Vol. 54, No. 5, 1022-1046, 2016.

[33] N. A. Mohd Nordin. Malaysian HEI student competency level. Master's paper, Universiti Kebangsaan Malaysia, Bandar Baru Bangi, 2015.

[34] Study International. How schools and teachers can promote student resilience, 2019. Available from https://www.studyi nternational.com/news/promote-student-resilience/ Accessed date 24.04.2020.

[35] A. S. Masten, M. J. Reed. Resilience in development. In C. R. Snyder, S. J. Lopez. (Eds.), Handbook of Positive Psychology. Oxford University Press, New York, NY, 117131, 2002.

[36] A. Rauch, M. Frese. Psychological approaches to entrepreneurial success: a general model and an overview of findings. International Review of Industrial and Organizational Psychology, Vol. 15, 101-142, 2002.

[37] A. S. Masten, K. M. Best, N. Garmezy. Resilience and development: contributions from the study of children who overcome adversity. Development and Psychopathology, Vol. 2, No. 4, 425-444, 1990. doi: $10.1017 /$ S0954579400005812

[38] E. Werner, R. Smith. Vulnerable but Invincible: A Longitudinal Study of Resilient Children and Youth. Adams, Bannister and Cox, New York, NY, 1982.

[39] I. Irmohizam, M. Hussin. Levels of resilience among public university students in Malaysia and overseas. Jurnal
Personalia Pelajar, Vol. 19, No. 1, 75-85, 2016.

[40] Global Entrepreneurship Research Association-GERA Global Entrepreneurship Monitor (GEM): Global Report 2017/2018. Global Entrepreneurship Research Association, London, UK, 2018.

[41] Malaysia. Ministry of Education. Putrajaya, Malaysia, 2017.

[42] A. Wahid, N. Hashim, A. Ibrahim. The relationship of the university environment to entrepreneurial intentions among entrepreneurship students. Journal of Global Business of Social Entrepreneurship, Vol. 1, No. 1, 136-149, 2017.

[43] N. N. Mohd Halid. Polytechnic and electrical engineering students' willingness in entrepreneurship. Master's paper, Universiti Tun Hussein Onn Malaysia, Batu Pahat, 2012.

[44] A. R. Madar, R. Abdul Hamid. A theoretical review on critical success factors (CSFS) of entrepreneurship programs in community college. International Journal of Sustainable Development \& World Policy, Vol. 3, No. 6, 138-145, 2014.

[45] N. Othman, R. Hussain. Evaluation of the implementation of the basic module of entrepreneurship in community college, Ministry of Higher Education. International Conference on Economics, Trade and Development, Vol. 36, 96-100, 2012.

[46] N.Z. Abd Rahim. The impact of entrepreneurship courses on student trends in entrepreneurship career opportunities. Master's paper, Universiti Kebangsaan Malaysia, Bandar Baru Bangi, 2017.

[47] NC4IR-TVET. Round Table Discussion: Economics, ROI, and entrepreneurship in the 4IR. National Conference on the 4th Industrial Revolution Skills Development: Road Map to the Future, 20 December 2017, Putrajaya, Malaysia, 2017.

[48] Y. Yusof. Entrepreneurial tendencies among urban college community college students. Master's thesis, Universiti Teknologi Malaysia, Skudai, Johor, 2012.

[49] Y. Boon, S. Z. M. Ilias. Factors influencing the choice of college profession among fourth-year inaugural students. Journal of Technical, Vocational and Engineering Education, Vol. 1, 22-40, 2011

[50] R. V. Krejcie, D. W. Morgan. Determining sample size for research activities. Educational and Psychological Measurement, 30, 607-610, 1970.

[51] U. Sekaran, R. Bougie. Research Methods for Business: A Skill-Building Approach. (5th Ed.), John Wiley \& Sons, Haddington, UK, 2010.

[52] E. McIntosh, J. Shaw. Student resilience: exploring the positive case for resilience, 2017. Available from https://www.researchgate.net/publication/321213371Studen tResilience_Exploring_the_Positive_Case_for_Resilience Accessed date 25.04.2020.

[53] N. Othman, J. Ab Wahab, H. Harun, R. Din, H. Ab Wahid. Establishing items of resilience and competitiveness among IPTs. Final research project: FRGS/1/2011/ss1/ukm/02/10. Universiti Kebangsaan, Malaysia, 2011.

[54] B. H. Din, A.R. Anuar, M. Usman. The effectiveness of the entrepreneurship education program in upgrading entrepreneurial skills among public university students. Procedia-Social and Behavioral Sciences, Vol. 224, 117123, 2016. doi: 10.1016/j.sbspro.2016.05.413. 
[55] H. Ab Wahid. Social entrepreneurship, resilience, and competitiveness of Malaysian IPT students. PhD thesis, Universiti Kebangsaan Malaysia, Bandar Baru Bangi, 2014.

[56] M. L. Harris, S. G. Gibson, Examining the entrepreneurial attitudes of US business students. Education + Training, Vol. 50, No. 7, 568-581, 2008.

[57] Ministry of Education. National education policy, 2020. Available from https://www.moe.gov.my/index.php/dasarm enu/dasar-pendidikan-kebangsaan Accessed date 24.04.2020.

[58] O. Fatoki, The impact of entrepreneurial; resilience on the success of small and medium enterprises in South Africa.
Sustainability, Vol. 10, No. 2527, 1-12, 2018.

[59] A. Iqbal, Y. Melhem, H. Kokash. Readiness of the university students towards entrepreneurship in Saudi private university: an exploratory study. European Scientific Journal, Vol. 8, No. 15, 109-131, 2012.

[60] D. Bakotic, D. Kruzic. Students' perceptions and intentions towards entrepreneurship: the empirical findings from Croatia. The Business Review, Vol. 14, No. 2, 209-215, 2010.

[61] M. Mohamad, J. Jaafar. Selection of entrepreneurial careers in Malaysian youth circles, 2016. Available from aplikasi04.polisas.edu.my/proceeding/index.php/.,

$1-15$ Accessed date 24.04.2020. 